\title{
Situational And Contingency Theories Of Leadership: Are They The Same?
}

\author{
Dr (Mrs.) Otaroghene Peretomode \\ Department of Petroleum Marketing \& Business Studies, Petroleum Training Institute, Effurun, Dleta State, \\ Nigeria.
}

\begin{abstract}
This paper is a positional, theoretical paper that explains comprehensively the all powerful but ambiguous concept of leadership, highlights its features and the categorization of its major theoretical approaches. It distinguishes clearly the two categorizations that neophytes and even scholars often used interchangeable as if both are the same. These broad categories are the situational and contingency theories of leadership. This distinction, it is believed, enables students to understand clearly the theories under each category but more importantly, it helps officials in Ministries of Education in developing countries to act most appropriately in a timely manner in intervening in worsening school administration with success in view.

Key Concepts; Administration, Consideration, Contingency theories, Leadership, Management, Maturity level, situational models, the behavioural approach, the 'great man' approach, the style approach, task - oriented, initiating structure,
\end{abstract}

\section{Introduction}

In Africa, there is the popular saying that the 'golden' fish has no place to hide, so also is the concept of leadership. Leadership as a concept is dynamic, fluid and complex hence in spite of its popularity, wide use and over 40,000 studies and writings on the subject, there is yet to emerge a universally accepted definition. Its popularity among the learned, literate and illiterate, is due to the fact that the success or failure of any nation or organization be it religious, profit or not-for - profit, public or private, is attributed to good leadership or poor leadership. The failure to have one generally accepted definition of the term could also be attributed to the argument made by McNamara $(1992,2009)$ that the concept of leadership is like a big "elephant" and each person standing around it has his/her own unique view, and each person feels very strongly about his/her own view. Similarly, an anonymous writer says "leadership is like pornography, hard to define but easy to recognize". To Bennis (1999), leadership is like beauty, it is hard to determine, but you know it when you see it. In this paper, we will briefly explain the concept of leadership, highlight its features, identify the different broad categories of leadership theories and then attempt to examine whether or not there are distinguishing characteristics between the situational category of leadership theories and that referred to as contingency leadership theories. Attempt will also be made to apply both categories to a hypothetical given school situation to determine the suitability and workability of each. First, let us examine the concept called leadership.

\section{Leadership: Meaning and Features:}

The concept of leadership can be traced to the Anglo - Saxon lad or laedan which means a path, a way, to lead or give a sense of direction. On this basis, leadership can be said to imply "the one who shows others the way". As Peretomode (2012) rightly argued, this explanation derived from the root word gives insight into what leadership is all about. Leadership, therefore, can be defined comprehensively and comprehensibly as: an art or process by which a member of a group or organization persuades, inspires, influences the attitudes, behaviour and actions of others and directs their activities so that the group or organization members work willingly, cooperatively and enthusiastically toward the accomplishment of set goals and a new and improved position (Peretomode, 2012: 10).

Leadership from this definition is different from management, or administration or the 'boss' - the head. It implies that the boss may not necessarily be the leader. This, however, does not preclude the fact that the boss who is the head by virtue of the position he or she occupies cannot transit to become a leader. It points, though to one basic fact of life, that the leader could be a person who does not necessarily occupy a position of power or authority. Such a person may be regarded as the informal leader in the organization.

A number of what could be considered as the features of leadership are self-evident from the definition given above and that is leadership:

- Involves other people. Without followers there can be no leader.

- It entails influence rather than authority

- It involves showing subordinates / followers the right way to go

- It focuses on achieving set goals 
- It is an on-going activity; a process. It is continuous.

- It involves an unequal distribution of influence between the leader and followers/ subordinates. It is thus a social influence relationship.

- It is a means to an end, rather than an end in itself.

- It produces positive change/improvement and not concerned with maintaining the status quo.

\section{Leadership Theories and their Broad categorizations}

In an effort to provide insight to the study and understanding of the complex phenomenon of leadership, over the years, there have been developed or propounded various perspectives, approaches, models and theories of leadership. Scholars have also made efforts to classify these theories in various ways namely; classical, behavioural, situational, contingency and emerging or contemporary theories and more. But while authors easily distinguish clearly between classical, behavioural / style and situational approaches to the study of leadership, they often do not attempt to make clear the distinction between situational and contingency theories of leadership, For example, Peretomode (1991), Onoyase (1992,2007), Ogunu (2000), Egwuyenga (2002), Lunenbury and Ornstein (2004), Hoy and Miskel (2005), Nakpodia (2006,2012) did not make efforts to distinguish between situational and contingency categories of leadership theories which are believed to be more robust and therefore preferred to the earlier models of leadership.

The failure to make clear the differences between both categories of leadership theories had led to students, even scholars, using both terms interchangeably as if they are the same, but they are not. Making clear the differences will enable educational managers or educational policy formulators or implementers to take appropriate and timely actions to arrest deteriorating school situations and to be able to turn such ugly situations around for the better, at the shortest possible time. Students of administration and management also need to know the distinction between situational and contingency categories of leadership theories in order to better appreciate and understand each of the theories under each broad category.

\section{The Common Threads}

A critical examination and analysis of the categories of situational leadership theories and that of contingency leadership approaches show that both categorizes are characterized by at least four common features. These are that:

1. Both categories are extension of behavioural group of leadership models

2. They contend that there is no one best or right way of successfully leading a group or an organization because a leadership style that is effective in one situation may be ineffective or a total failure in another situation.

3. A successful leader in a given situation may become a failure in the same position in the same organization when factors around the situation change.

4. They assume that the effectiveness of leadership styles are determined by factors internal and external to the organization, within the leader and employees or followers and the leaders skills and the maturity levels of followers.

\section{The Differences}

We have explained that there are certain common elements or similarities between theories broadly classified as situational and those referred to as contingency theories of leadership. Despite this fact, there seems to be two very distinctive characteristics between the two. According to Syque (2007), situational theories tend to focus more on the behaviors that the leader should adopt, given the followers' behaviour, whereas contingency theories take a broader perspective that include situational factors about leader skills and capability and other variables within the given situation.

This author agrees with the explanation put forward by Peretomode (2012) that the difference between situational and contingency theories of leadership is clearer and more meaningful if viewed from the basic assumption that underpin each category in respect to the rigidity or otherwise of leadership styles. Situational theories presume that leadership style is relatively flexible, and indeed flexible enough for a leader to move along a continuum front and back so as to enable him/her cope with different situations. In effect, the situational category of leadership theories claim that it is possible for a dictator or task oriented leader to change his style to become a democratic or employee oriented leader, as the situation changes. The core of the argument therefore, is that effective or successful leaders are those who change their style to fit the situation. Thus, to situational theories, effectiveness of leaders depends on successfully diagnosing where subordinates are on the development continuum and adapting their leadership style as necessary.

Some theories of leadership that can be clearly classified under the situational category are:

- The Tannenbaum and Schmidst's leadership model

- The Reddin's -3- theory of leadership

- The Path - Goal Theory of Leadership

- The Hersey and Blanchard' Situational Leadership Theory. 
Situational And Contingency Thories Of Leadership: Are They The Same?

While both categories of theories have similar shortcomings, there is one which is unique to situational theories. While presuming that style is relatively flexible and therefore the leader can move up and down the continuum and from being a dictator to becoming a democratic leader, given the situation, it failed to give or prescribe a time frame for doing so. What is the average duration for a leader to be able to change his or her style from A to B? This we are not told. Any how, this required change also depends on a number of personal factors or characteristics of the leader - his / her personality, maturity level, intelligence and sensitivity to events happening around him, his/her education and training, skills and ability to diagnose correctly and quickly the direction the school is headed, especially when it is a negative and unsuitable direction for teaching and learning.

However, unlike situational theories, contingency leadership theories are based on the premise that leadership styles are fairly rigid or relatively inflexible. Therefore, it is very difficult, if not impossible, for a dictator or a task oriented leader to change his / her style to becoming a participative or employee oriented leader. This category, therefore, suggests that for a school head to be successful or effective, the officials in the Ministry of Education in charge of deployment and re-deployment of school heads should be able to diagnose a school situation and select a leader with an appropriate style to match the situation. Typical examples of theories of leadership that can be classified under the contingency category are:

- Fielder's contingency theory of leadership effectiveness

- Cognitive resource theory, and

- Strategic contingencies theory (Peretomode, 2012: 106)

Examples of Situational Leadership Models

Two of such models will be concisely discussed here. First is the Tannenbaum and Schmidt's Leadership Continuum Model. Tannenbaum and Schmidt (1975) were among the pioneers to describe various factors (within the manager, the subordinates and the situation) they believed influenced a manager's choice of leadership style. They put the factors in a continuum varying from leader-centered / boss centered (autocratic) to subordinate-centered (democratic). The authors pointed out that a leader should not choose a strict 'autocratic' or democratic style but should be flexible enough to be able to choose a style to cope with different situations. They opined that as subordinates develop their maturity / capability, the leader who begins with most of the control should now gradually pass this over to the subordinates. The figure 1 is a vivid illustration of the assumed flexibility of leadership style to move front and back on a continuum in order to be successful or effective.

\begin{tabular}{|c|c|c|c|c|c|c|}
\hline Boss - & $\begin{array}{l}\text { Centered } \\
\text { eadership }\end{array}$ & & & & $\begin{array}{l}\text { Subordin } \\
\text { Leadersh }\end{array}$ & ate - Centered \\
\hline \multicolumn{7}{|c|}{$\begin{array}{l}\text { Use of Authority } \\
\text { By the Manager }\end{array}$} \\
\hline & & & & & & $\begin{array}{l}\text { Area of Freedom } \\
\text { For Subordinates }\end{array}$ \\
\hline $\begin{array}{l}\text { Manager } \\
\text { makes } \\
\text { Decision } \\
\text { and } \\
\text { Announces } \\
\text { it }\end{array}$ & $\begin{array}{l}\text { Tanager } \\
\text { "sells" } \\
\text { decision } \\
\text { der }\end{array}$ & $\begin{array}{l}\quad \text { 个 } \\
\text { Manager } \\
\text { Presents } \\
\text { Idea and } \\
\text { Invites } \\
\text { questions. }\end{array}$ & \begin{tabular}{l}
\multicolumn{1}{c}{$\uparrow$} \\
Manager \\
Presents \\
Tentative \\
Decision \\
Subject \\
To change
\end{tabular} & $\begin{array}{l} \\
\text { Manager } \\
\text { Presents } \\
\text { Problems, } \\
\text { Gets } \\
\text { Suggestions } \\
\text { Makes } \\
\text { Decisions }\end{array}$ & $\begin{array}{l}\text { † } \\
\text { Manager } \\
\text { Defines } \\
\text { Limits; } \\
\text { Asks } \\
\text { Group } \\
\text { To } \\
\text { Make } \\
\text { Decision }\end{array}$ & $\begin{array}{l}\text { Manager } \\
\text { Permits } \\
\text { Subordinates to } \\
\text { Function } \\
\text { Within limits } \\
\text { Defined by } \\
\text { Superior }\end{array}$ \\
\hline
\end{tabular}

Fig. 1: Tennenbaum and Schimdt's Leadership Style Continuum

A second example of situational leadership theory is the Hersey and Blanchard's Situational Leadership Theory, an extension of the Tannenbaum and Schmidt's leadership style continuum. Hersey and Blanchard (1977) derived four basic leadership styles based on the dichotomization of each of the two traditional categories of leader behaviour namely initiating structure and consideration. The four styles they came up with were telling (directing), selling (coaching), participating (supporting), and delegating. The authors also introduced another dimension - maturity level of the subordinates, to the theory. They defined 'maturity' not in terms of age, emotional stability or physique, but a desire or readiness and ability to tackle the task facing the group. They identified four maturity levels to be:

$\mathrm{M} 1 \quad=\quad$ Low readiness level

$\mathrm{M} 2=$ Moderate readiness level

M3 = High readiness level, and

M4 = Very high readiness level.

Hersey and Blanchard then explained that effectiveness of leaders very much depends on their ability to successfully diagnose where subordinates are on the maturity continuum and adapting leadership style as 
necessary. They suggested that leaders should match their style to the maturity level of subordinates as shown in figure 2.

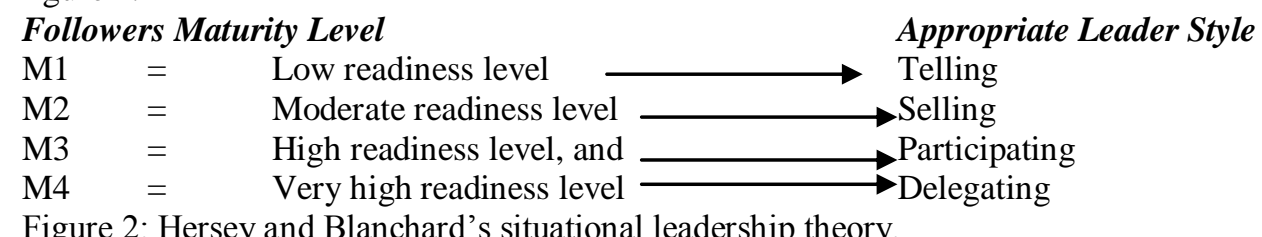

Figure 2: Hersey and Blanchard's situational leadership theory.

In effect, the theory emphasizes leader style flexibility in order to be successful.

An Example of Contingency Theory

One early leadership theory that belongs to the contingency category will be discussed briefly here. It is the Fiedler's Contingency Theory of Leadership Effectiveness. Fiedler argues that leader effectiveness is dependent on the interaction of the leader's style and characteristics of the situation defined as leader-member relations, task - structure and leader - position power. According to Fielder, the three characteristics in a situation when combined will permit classification of three situations namely:

1. Very Favourable Situation: when all three critical elements are high.

2. Intermediate Favourableness: a condition when some of the situational characteristics are poor / low and others are good / or high.

3. Unfavourable Situation: a situation where all three situational components are low or poor.

Fiedler recognized two types of leadership style namely task - oriented (TO) and relationship

Oriented $(\mathrm{RO})$. He argued that the two styles are relatively inflexible and no one style is appropriate for every situation. He maintained, however, that both types of leaders can be effective, each given the right situation. The best way to achieve result, therefore, is to match the manger's style to a given suitable situation (or train the leader to change the situation to match or fit his own style as later suggested by Fiedler, Chemers and Mahar, (1976). This latter addition to the theory, this author believes , complicates the original theory being discussed here as that takes time and the situation may not be amenable to change.

Based on the findings of several of his researches, Fiedler concluded as follows:

1. Task Oriented (TO) leaders tend to be more effective than Relationship Oriented (RO) leaders in two of the three identified situations - in highly favourable and unfavourable situations, and

2. Relationship Oriented (RO) leaders tend to be more effective than TO leaders in situations of intermediate favourableness.

Why an Understanding of the Differences between the Categories of Situational and Contingency Leadership Theories is Necessary

The importance of clearly understanding the differences between the categories of leadership theories referred to as situational and that category called contingency theories in developing countries such as Nigeria cannot be over - emphasized. The Universal Basic Education (that is the six year primary and first three years of secondary education) and Senior Secondary Schools are under the supervision of the Universal Basic Education Board and the Secondary Education Board respectively (i.e. Basic and Secondary Education Board) in each state in Nigeria. The boards are in turn under the Supervision of the Ministry of Education in each State. The three situations identified, for example, by Fiedler can be associated with our Secondary Schools - those that are very good schools (with dedicated teachers, serious students, good facilities and good governance). There are also those which are "bad and ugly" - very unfavourable schools, with poor leadership, uncommitted staff, poor facilities and unserious students with uncooperative communities. In such schools, students either refuse to go to school, or go to school late every day, get to class late and unprepared to learn, and with serious disciplinary problems. There is also a third category with, may be, a poor school head, fairly committed teachers and average students and cooperative community. According to Fiedler, this is typically an example of an intermediate favourable school. The ideas from situational and contingency theories will enable officials of the Ministry of Education, if they are trained professional educational administrators, to know what to do in the interest of education and our children. From the personal experience of the author, the Fiedler's contingency theory holds sway here as a useful framework and a guide to educational managers.

In a very unfavourable school situation, if officials in Ministry of Education believe in situational leadership theory, it implies they will sit back and relax hoping that the school head, called the Principal, would gradually change his / her style (aloof style) to a more directive, task - oriented leadership style to fit the worsening situation in order to turn it around for good. This would amount to inviting disaster to that school as the school Principal may never change his / her style to match the deteriorating situation at hand. In such an extreme situation, the contingency approach is more desirable as it demands prompt action to correcting an undesirable situation. In this case, contingency approach, presuming that leadership style is relatively inflexible, would source from among its pool of principals, a no-nonsense, goal directed principal and deploy him or her immediately to head such a school and to turn it around for good. As Fiedler pointed out from the findings of his 
Situational And Contingency Thories Of Leadership: Are They The Same?

numerous studies, task-oriented (OT) leader tends to be more effective than relationship oriented (RO) leader in an unfavourable situation and highly favourable situation. In the situation of intermediate favorableness, relationship oriented principal should be preferred. The Fielder's leadership framework, therefore, is a useful model that Ministry of education officials must have a clear knowledge and understanding of and the applicability of that theory in times when certain schools are under-achieving due to problems of uncommitted and undisciplined staff and problematic student body.

\section{Conclusion}

The article examined the popular concept of leadership, highlights its features and importance in the success of any school administration. It discussed the categorization of leadership theories and made clear the distinction between the category of leadership perspectives called situational models and that referred to as contingency leadership theories. It applied the categories to a hypothetically worsening school situation and concluded that the contingency theory is more appropriate and workable in such a situation. It argued that education mangers in the Ministry of Education need a clear understanding of both categories of leadership, understand their differences and more importantly be able to apply Fielder's theory of leadership effectiveness to worsening school situations. One implication of this recommendation is that officials in Ministries of Education in Nigeria should have a clear knowledge of the personality and leadership styles of the hundreds of school heads in their pay roll to be able to deploy any one of them whose leadership style best matches a given school situation so that our schools can continue on the path of improvement and success in achieving national education goals.

\section{References}

[1] Bennis, W. G. (1999). "An invented life: reflections on leadership and change: Retrieved July 23 , 2012 from http://www.cio.com/research/executive/edit/chapter5.html

[2] Egwuyenga, E. (2002). Essentials of School Administration. Benin City: Justice Jeco.

[3] Fiedler, Fred E. (1976). "The leadership game; matching the man to the situations". Organizational dynamics, (Winter); 6 - 16.

[4] Fiedler, Fred E. (1967). A theory of leadership effectiveness. New York: McGraw-Hill and Mahar, L.

[5] Fiedler, Fred E., Chemers, Martin M. (1976) Improving leadership effectiveness. The Leader match concept. New York: Wiley.

[6] Hersey, P. and Blanchard, K. H. (1977) Management of organizational behaviour, utilizing human resources, $3^{\text {rd }}$ ed Englewood Cliffs, N. J.: Prentice - Hall.

[7] Hoy, Wayne K. \& Miskel, Cecil G (2005) Educational Administration: Theory, Research and practice $7^{\text {th }}$ Edition - New York: McGraw - Hill Co.

[8] Lunenburg, Fred C. and Oristein, Allan C. (2004). Educational Administration: Concepts and Practices ${ }^{\text {th }}$ Ed. Belmon, C. A; Wadsworth / Thomas Learning.

[9] Nakpodia, E.D. (2006). Educational Administration: A New Approach, $2^{\text {nd }}$ ed. Warri: Jonokase Nig.Co.

[10] Nakpodia, E. D. (2012). Principles of School Administration. Abraka : Delsu Printing Press

[11] Ogunu, Michael (2000). Introduction to Educational management. Benin City: Ambik.

[12] Onoyase, D. (1992). Theory and Practice of Educational Administration, $2^{\text {nd }}$ Ed. Warri: Johanny \& Co. Ltd.

[13] Peretomode, V.F. (1991). Educational Administration: Applied Concepts and Theoretical Perspectives for Students and Practitioners. Lagos: Joja Research \& Publishers Ltd.

[14] Peretomode, V. F. (2012). Theories of management: Implications for educational administration. Benin City: Justice Jeco Publishing Global.

[15] Reddin, W. J. (1970) Management effectiveness. New York: McGraw - Hill

[16] Syque, R. (2007). Leadership vs. management. Retrieved July 29, 2012 www.articlelick.com

[17] Tannenbaum, R. and Schmidt W. H. (1975) "How to choose a leadership pattern" Harvard Business Review (May - June): 162 180 